\title{
Study of Medial and Conceptional Orality in the Retrato de la Loçana andaluza
}

\author{
ROCÍO DÍAZ-BRAVO
}

University of Granada

\begin{abstract}
In this article, I analyse the orality of a sixteenth-century Spanish literary text, the Retrato de la Loçana andaluza (RLA), composed in Rome (1524) by the Andalusian priest Francisco Delicado. This work reflects the multilingual situation of Rome during that time and is also an example of a text specifically designed to be read aloud in public. The following hypothesis has been proved: the RLA is a remarkable example of a text written in sixteenth-century Spanish that can be used for studying both medial and conceptional orality (as defined by Koch and Oesterreicher 2007). The text of the only surviving antique copy of this book was consciously written taking into account its way of dissemination: public reading (aloud in groups). Furthermore, Delicado uses features of the spoken language to portray characters and communicative situations, and to imitate the mechanisms and strategies of oral dialogicity.
\end{abstract}

\section{Resumen}

En este artículo, analizo la oralidad de un texto literario español del siglo XVI, el Retrato de la Loçana andaluza (RLA), compuesto en Roma (1524) por Francisco Delicado. Esta obra refleja la situación plurilingüe de la Roma de aquel tiempo, y además es un texto gráficamente configurado para ser leído en voz alta. Se demuestra la siguiente hipótesis: el RLA es un ejemplo excepcional de un texto escrito en el siglo xvi que puede usarse para estudiar la oralidad medial y concepcional (los dos tipos de oralidad distinguidos por Koch y Oesterreicher 2007). La configuración gráfica de la única copia antigua de este libro fue concebida teniendo en cuenta su modo de transmisión: la lectura en voz alta ante un grupo de lectores-oyentes. Asimismo, Delicado utiliza rasgos de la lengua oral para caracterizar personajes y situaciones comunicativas, así como para imitar los mecanismos y estrategias de la dialogicidad oral.

The study of the spoken language is one of the most recent areas of interest in the history of the Spanish language. The aim of this article is to show the results of a linguistic analysis of the orality of a literary text composed in Rome in 1524 by

1 See, for example, Koch and Oesterreicher 2007; Fernández Alcaide 2009; Sánchez Méndez 2012; Calderón Campos 2015. 
the Andalusian Humanist Francisco Delicado: the Retrato de la Loçana andaluza (or $R L A){ }^{2}$ This work reproduces the multilingual situation of sixteenth-century Italy, and is also an example of a text specifically designed to be read aloud in public.

The present research contributes to the study of the orality in early modern Europe from a linguistic point of view, especially to the history of spoken Spanish. It also contributes to the study of the $R L A$, within a linguistic framework. Due to its initial history of more than three centuries of absolute silence, to the difficulties in obtaining this literary text after its discovery by Ferdinand Wolf in 1845 in the Austrian National Library (which contains the only surviving early modern edition of the book), and to its sexual content, the RLA is only starting to receive the status that it deserves. It is attracting an increasing interest from many scholars, students and a general audience in recent years and is ripe for further study.

\section{Research questions, theoretical framework and hypotheses}

Having assumed that it is possible to find features of orality in a written text (Cohen and Twomey 2015; Oesterreicher 2004a) and that the RLA is an excellent source for its study, this article investigates: What kinds of orality can be found? In which discourse types does it appear? What features were chosen by the author to represent this orality? What was the purpose of using it?

In addition, this article aims to prove that the RLA is a remarkable example of the texts written in sixteenth-century Spanish to study both types of orality defined by Koch and Oesterreicher (2007): medial and conceptional orality. Their proposed model differentiates between medium (phonic versus graphic) and conception (conceptional orality or communicative immediacy versus closeness versus conceptional writtenness or communicative distance) (Figure 1).

Furthermore, they established a continuum between the prototypical communicative immediacy (normally phonic, informal, spontaneous, non-standard) and the prototypical communicative distance (normally graphic, formal, planned, standard). ${ }^{3}$ Any type of text can be placed in this continuum: its closer location to the pole of communicative distance or to the extreme of communicative immediacy will depend on a combination of parameters such as formality, physical immediacy or distance, spontaneity, etc. For some examples of discourse traditions ${ }^{4}$ resulting from the combination of medium and conception, see Table 1.

2 This article is a revised summary of my unpublished $\mathrm{PhD}$ thesis.

3 Please see Koch and Oesterreicher 2007: 33-34 for more details about the concepts of conceptional orality or communicative immediacy and conceptional writtenness or communicative distance.

4 Most of the examples selected are existing discourse traditions in early modern Spain and Europe, many of which were presented during the conference 'Gossip, Gospel and Governance: Orality in Europe (1400-1700)' (London, July 2011). 
Phonic MEDIUM

A

Communicative immediacy

Spoken CONCEPTION

Conceptional orality
B

Communicative distance

Written CONCEPTION

Conceptional writtenness

C

D

Graphic MEDIUM

Figure 1. Distinction medium/conception

Source: Adapted from Koch 1999: 400; translated/adapted from Oesterreicher 2004a: 735.

Table 1. Examples of discourse traditions resulting from the combination of medium and conception

\begin{tabular}{|c|c|c|c|}
\hline & & \multicolumn{2}{|c|}{ CONCEPTION } \\
\hline & & Conceptional orality & Conceptional writtenness \\
\hline \multirow[t]{2}{*}{ MEDIUM } & $\begin{array}{l}\text { Phonic } \\
\text { medium }\end{array}$ & $\begin{array}{l}\text { A (spoken phonic model) } \\
\text { - Spontaneous everyday } \\
\text { conversation }\end{array}$ & $\begin{array}{l}\text { B (written phonic model) } \\
\text { - Oral academic instruction } \\
\text { - Sermons } \\
\text { - Funeral oration } \\
\text { - Letter of testament } \\
\text { - Spoken discourse in royal } \\
\quad \text { elections } \\
\text { - Ballads and songs traditions }\end{array}$ \\
\hline & $\begin{array}{l}\text { Graphic } \\
\text { medium }\end{array}$ & $\begin{array}{l}\text { C (spoken graphic model) } \\
\text { - Spontaneous private } \\
\text { correspondence } \\
\text { - Dialogue within grammars } \\
\text { - Novel in dialogue } \\
\text { - Picaresque novel } \\
\text { - Witness' declaration within } \\
\text { judicial/ inquisitorial acts }\end{array}$ & $\begin{array}{l}\text { D (written graphic model) } \\
\text { - Notarial document } \\
\text { - Essay } \\
\text { - Medical text } \\
\text { - Expositive text }\end{array}$ \\
\hline
\end{tabular}

According to this model, the dialogues of a literary work whose author tries to mimic spontaneous conversations belong to area $\mathrm{C}$ : graphic medium and oral conception. Delicado uses features of spoken language in order to portray characters and communicative situations, and to imitate the mechanisms and strategies of oral dialogicity, especially, in the sequences of the text that I have classified as 'prototypical oral interaction' - in other words, the discourse type which best imitates the spontaneous conversation (Díaz-Bravo 2010a: 53, Díaz-Bravo and Fernández Alcaide 2018: 362). However, there are excerpts that represent 'the 
written graphic' model (area D): the narrative, expositive and argumentative parts. In addition, the notion of 'medium transferability' implies that a spoken text (phonic medium) can be transcribed (graphic medium) and that a written text (graphic medium) can be read aloud (phonic medium) (Lyons 1981: 11). In terms of medial orality, it seems very likely that the text of the only surviving original of the RLA was consciously written taking into account its way of dissemination: public reading (aloud in groups), as proved by some linguistic features such as contextual letters or the union of words. ${ }^{5}$ In the early modern period, the concept of readers was used for both 'letores' (Delicado 1530?: 53v) ('reader': the person who reads aloud) and 'audientes' (Delicado 1530?: 53v) ('listeners': the people who listen to the one reading aloud) (Frenk 1982; 1992).

\section{The author and his literary work in context}

The Retrato de la Loçana andaluza was written by Francisco Delicado, an Andalusian priest who migrated to Italy, like his protagonist, Loçana. Through his texts it is possible to ascertain some biographical details. He lived in Rome, where he wrote the work set to make him famous: the RLA. After the sack of Rome (1527), Delicado went to Venice, where he worked as a proofreader in the workshop of the Nicolini da Sabbio. Delicado added a number of texts to some 'bestsellers' of the Spanish literature of that period: Tragicomedia de Calisto y Melibea (Venice 1531; Venice 1534) (Delicado 1531 and 1534a), Amadís de Gaula (Venice 1533) (Delicado 1533) and Primaleón (Venice 1534) (Delicado 1534b). His work included writing prologues, colophons and other relevant texts for these literary works, where he highlighted the importance and prestige of the Spanish language and literature in Italy. Furthermore, he was the first person who wrote a 'guide for pronunciation', contrasting Italian and Spanish.

As a literary author, Francisco Delicado selects the oral features that he intends to represent. It is possible to state that Delicado has the typical self-awareness of a literary author and could almost be considered one of the early-modern grammarians (Díaz-Bravo 2019b: 155). Most of the data permitting analysis of the linguistic self-awareness of Francisco Delicado (both internal and external) are found in his prologues, colophons and 'guides for pronunciation' added to the literary works that he edited in Venice. ${ }^{6}$

5 The only surviving original is currently held in the National Library of Austria in Vienna, 66.G.30.(3). A facsimile edition, available online by the Biblioteca Virtual Miguel de Cervantes, was published in 1950 by Antonio Pérez Gómez. In addition, the facsimile images of the only surviving original can be downloaded since 2016, through the catalogue of the Austrian National Library: <http://digital.onb.ac.at/RepViewer/viewer.faces?doc=DTL_6316301>.

These images, thanks to the permissions granted by the Austrian National Library, have been incorporated into a new digital edition of the RLA: Lozana Digital (Díaz-Bravo and Vaamonde 2019). This edition, specifically designed for linguistic analysis of this literary work, preserves the original paragraphs, line breaks and folio numbers of the book held in Vienna. The examples and folio numbers cited in this article are taken from this digital edition.

6 On the one hand, the internal linguistic self-awareness can be defined as that which is directly related to the linguistic system, including concepts of word, phoneme, polysemy 
Analysis of the internal linguistic self-awareness on the phonic level is especially relevant to the study of medial orality. ${ }^{7}$ The brief texts added to his Venetian editions of the highlights of Spanish literature for an Italian audience illustrate the importance he attached to correct pronunciation of Spanish. These 'guides for pronunciation' can be considered brief treatises of contrastive phonetics where Delicado (1533: A2r-A2v; 1534a: O3r-O4v; 1534b: KK6v-KK7r) examines the main differences between Spanish and Italian letters and syllables, and this should be taken into account by those who want to read the Spanish language correctly. These texts are not just treatises for teaching Spanish pronunciation to foreigners (in particular, to Italians), or 'reglas de ortografía castellana y de fonética contrastiva con el italiano' (Perugini 2004: XXXV). They should mainly be considered guides for correct pronunciation of Spanish to help Italians read aloud, as declared by Delicado:

El Delicado corrector esta buelta dela presente estampa en Venecia dize assí: porque es cosa necessaria \& conueniente alos auenir que aman la habla castellana o española en romance, auiéndose impresso esta obra en Ytalia \& auiéndola assí mismo a leer en todas las partes de Ytalia, por ser tan preciada a todos estrangeros, les declaramos estos vocablos ${ }^{8}$ en que no tropeçasen, que al menos los puedan entender y profferir según el arte uerdadero de su natural pronunciación. Algunos digo delos que solamente enel profferir está la diferencia \& la causa principal de la Orthographía castellana o española en el su romance, para que mejor gozen dela obra, que les será entender las razones enteras que hacen sentencias claras donde con mucha facilidad todos los libros de nuestro común hablar entenderán con poco trauajo. (Delicado 1533: A2r; 1534b: KK6v)

Analysis of external linguistic self-awareness is useful for the study of the historical language features of the Spanish language spoken in the sixteenth century. ${ }^{9}$ Delicado (1534a: O4r) is aware of the existence of the prestigious 'romance castellano' [vernacular Castilian] language, which is called 'española' [Spanish] in Italy. Moreover, he knows that it is a literary and 'pelegrina' [migratory] language (Delicado 1533: A1v). He believes in the authority of the standard language of Toledo, thinking it more 'elegante' (Delicado 1533: A1v). He adds he is writing the RLA in 'la lengua de la polida Andaluzía' [the language of the polished Andalusia]: 'por mejor la arrendar en la manera de su hablar' [in order to mimic her (Lozana) better in her way of speaking] (Delicado 1534b: Z1v). The language spoken in Andalusia is considered a variety of the communicative immediacy (the spoken language); according to Delicado, it is the best variety after Toledan Spanish (the variety of communicative distance).

(Gauger 2004: 682). On the other hand, the external linguistic self-awareness is related to attitudes and opinions about a particular language or variety; as well as to matters such as the standardization of a language versus its dialects (Gauger 2004: 682-83).

7 See a more detailed analysis in Díaz-Bravo 2019b: 141-45.

8 These vocablos are clearly related to pronunciation, as defined by Covarrubias (2011) (s.v.): 'qualquiera dición, porque no se puede pronunciar sin vocal'.

9 See a more detailed analysis in Díaz-Bravo 2019b: 145-55. 
The language of Toledo achieved the status of standard variety after Castilian was consolidated as a standard language. Although its status began to decline from the second half of the sixteenth century (after the Court moved to El Escorial, near Madrid), when the RLA was written and published, Toledan Spanish was still the most prestigious. Another prestigious linguistic norm of that period was that of Seville (Andalusia). However, the higher status of Castilian versus other varieties was not questioned in the Golden Age Spanish linguistic debate (see Anipa 2001: 39-60).

Asensio (1961) started a controversy on Valdés versus Delicado, which was refuted by Guitarte (1979). According to Asensio (1961), Toledan Valdés' comments (1535?) against Amadís (authority in style) and against Andalusian Nebrija (authority in language) are an indirect reply to Delicado's praises for both the aforementioned work and the grammarian, as well as for Andalusian Spanish. However, as explained by Bubnova (2001: 89), given that Valdés does not mention either Delicado or a specific edition of Amadís, it is difficult to defend or to refute the hypothesis that Valdés is actually referring to Delicado's edition. In any case, it is clear that, despite praising Andalusian Spanish, Delicado did not question the higher status and prestige of Toledan Spanish (Guitarte 1979: 166-67).

Delicado aimed 'to reproduce spoken and non-standard linguistic forms, which were commonly used during his time' when creating the RLA (Anipa 2001: 9). As Delicado (1530?: 52v-53r) explicitly states, the variety chosen for his literary work is his mother language ('la lengua materna'): Spanish spoken in Andalusia. Anipa (2001: 10) has remarked that Delicado's words 'entre mugeres' should not be misinterpreted 'as his adherence to one specific sociolect: the feminine speech', but 'rather as emphasizing the colloquial and spontaneous nature of the language that he wants to record'. As 'women are generally believed to be more active in gossip than men, his reference to them simply implies the way in which people speak ordinarily or casually while gossiping'. The Spanish spoken in Andalusia was chosen by Delicado to record not only Lozana's voice but also other characters' conversations in the city of Rome, in its houses and streets.

According to Delicado, the RLA was composed in Rome in 1524 (Delicado 1530?: 52r); however, it was later published anonymously in Venice with the following title: Retrato de la Loçana andaluza en lengua española muy claríssima. Conpuesto en Roma. El qual retrato demuestra lo que en Roma passaua y contiene munchas más cosas que la Celestina. ${ }^{10}$ My interpretation of the words 'muy claríssima' is 'very easy to understand', as it was the language spoken in everyday conversation. It is a deliberate decision to keep the word retrato [portrait] in the title of this article, as newer editions usually have failed to appreciate its importance. Its author inten-

10 One of the main reasons why it was published anonymously and why there is only one surviving original is the sexual content of the book, as the main character, Lozana, is a prostitute. It can be compared to La Corteggiana (Giordano and Calvo 2000) and I Modi (Ávila 2008), written by Prieto Aretino in Italy during the same period. The latter is a collection of sonnets and images illustrating the sexual positions described in each poem. It was published in Venice around 1527 and there is only one surviving copy (in Geneva), which is incomplete (Giordano and Calvo 2000: 9). 
tionally used the word retrato with a very clear purpose. Delicado wanted to create a portrait not only of his main character, the prostitute Loçana, but also of Rome during the period prior to the 1527 sack. He emphasized his intention to make a portrait of the Spanish spoken in Rome, as language is one of the most powerful resources to characterize people in literary works (Bubnova 1987: 182). ${ }^{11}$

The communicative space where the major part of the action happens is Rome. Sixteenth-century Rome was a multicultural and multilingual city. In his Retrato, Delicado wants to portray the spoken language of the characters of various nationalities, ethnicities, religions, social classes and occupations, both women and men. Multilingual Rome is reflected in the RLA, since several languages are used in the dialogues: Spanish is the main language, but we can find also Italian, Catalan, Portuguese and Latin. ${ }^{12}$

The spaces where the text was first presented to the public include, after Rome, other Italian cities (especially Venice). Spanish was very prestigious ${ }^{13}$ in sixteenthcentury Italy, with many Spanish literary works published by Italian presses (see Pallota 1991 and Bognolo 2012). While Delicado was setting up the graphic configuration of his writing, he had in mind the reception of his literary work. He was aware that it would be read by an audience of Spaniards and Italians living in Rome and that, after its publication in Venice, it would be also available to readers in other Italian cities. Southern Italy, the Kingdom of Naples, was under Spanish dominance. Consequently, Spanish assumed important functions as the language of the communicative distance and the communicative immediacy in Naples (Gruber 2008 and Oesterreicher 2004b).

The number of characters 'who speak' in the work is controversial. Delicado (Delicado 1530?: 52r); mentions in the explicit at the end of the book that there are 125 characters: 'çiento y veynte e çinco' 'personas que hablan'. However, after making a social classification of all the characters, I have counted 139 characters, 135 of whom 'speak' (cf. Allaigre 2004; Díaz-Bravo 2019a: 191-98). ${ }^{14}$ The protagonist of the book, Lozana, speaks to various characters in private places (for example, to

11 Bubnova (1987: 173-88) studied language characterization in the RLA and offered a brief analysis of some linguistic oral features (1987: 180-88), such as polysyndeton. In her book, she applied Mijaíl Bajtín's theories and concepts (such as novelistic 'polyphony', characterization through language, carnival, etc.) to the RLA.

12 Multilingual Rome is also reflected in Torres Naharro's Propalladia (1517). For instance, different characters in his Tinellaria speak - besides Spanish - Italian, Portuguese, French and Catalan. Gruber (2014) examines multilingualism in the Kingdom of Naples while it was under Spanish rule (1503-1713), with a focus on Spanish. In her corpus, she included authors such as Delicado, Torres Naharro and Juan de Valdés. See also Krefeld, Oesterreicher and Schwägerl-Melchior 2013 for a study of multilingualism in the Spanish Italy from the fifteenth to the seventeenth century.

13 The prestige of the Spanish language in sixteenth-century Italy is mentioned by, among others, Juan de Valdés: 'porque como veis ya en ytalia assi entre Damas como entre Caualleros se tiene por gentileza y galania saber hablar Castellano’ (Valdés 1535?: 36).

14 Díaz-Bravo (2019a: 191-98) provides a revised table containing all the characters in the RLA, as well as their different names and the 'mamotretos' or chapters where they appear. Additionally, Díaz-Bravo (2010a: 693-706) provides variables useful for a sociolinguistic analysis: occupation, education, place of origin, age, gender, religion, etc. 
her male and female customers) and in the streets. As a prostitute, she has male customers, but she also supplies various services to women (she works both as a procuress and as an aesthetician). One of the main characters is Lozana's servant and lover, the young Rampín. Both a) the large number of characters of different social classes, nationalities, ethnicities, religions... and b) the complex structure of the literary work make of the RLA an ideal source for the study of linguistic variation and orality in early modern Europe.

The book consists of three parts divided into sixty-six 'mamotretos' or sketchbooks (the portrait), preceded by a dedication (a un 'Illustre señor') (Delicado 1530?: 2r), and a plot: 'Argumento en el qual se contienen todas las particularidades que á de auer en la presente obra') (Delicado 1530?: 2r), and followed by a number of texts: an essay ('Cómo se escusa el Autor en la fin del Retrato de la Loçana, en laude de las mugeres') a table or explicit (Delicado 1530?: 52v-53r), an epistle from the author (Delicado 1530?: 53r-53v), a letter in verse ('Carta de excomunión contra vna cruel donzella de sanidad') (Delicado 1530?: 53v), an epistle from Loçana ('Epístola de la Loçana a todas las que determinauan venir a uer Canpo de Flor en Roma') (Delicado 1530?: 54r), and an epilogue ('Digressión que cuenta el autor en Venecia') (Delicado 1530?: 54v).

\section{Methodology and corpus}

Based on the aforementioned theoretical framework, Oesterreicher (2004a) offered methodological keys to researching conceptional orality in the texts that represent the spoken graphic model (Figure 1 and Table 1: see area C). He proposed a typology of texts characterized by communicative immediacy, in order to study conceptional orality in Golden Age Spanish: texts written by semi-literate (e.g., some letters written from Hispanic America), transcriptions of oral speech (e.g., inquisitorial acts), writing in estilo llano [plain style] (e.g., Santa Teresa) (cf. Pountain 2016), grammarians' and writers' metalinguistic comments (e.g., Juan de Valdés), mimetic or simulated orality found in literary texts (e.g., plays), etc. From the latter group, he cites the RLA as an exceptional example (Oesterreicher 2004a: 755).

To study conceptional orality in the RLA, I have divided the text into different discourse types: argumentative writing, expository writing, narration, epistle (formal, informal), monologue (monologue, aside) and dialogue (prototypical oral interaction or conversational dialogue, argumentative dialogue, expositive dialogue, dialogue with a narrative function: narrative dialogue, oral narration and oral reproduction of reported speech). The discourse complexity of this literary work, as a result of the structural complexity mentioned above, is shown in Table 2.

I have applied the universal communicative parameters established by Koch and Oesterreicher (2007: 26-27) to each of these discourse types: a) degree of publicity (public, private, intimate); b) degree of familiarity between the participants of the conversation; c) degree of emotional implication; d) degree of anchorage; e) referential field; f) physical immediacy of the interlocutors; g) degree of cooperation; 
Table 2. Structural complexity $=$ discourse complexity

\begin{tabular}{|c|c|}
\hline $\begin{array}{l}\text { Structure of the } \\
\text { Retrato de la Loçana andaluza }\end{array}$ & Discourse varieties \\
\hline Dedication ('Illustre señor') & Formal epistle \\
\hline Argument & Argumentative text \\
\hline $\begin{array}{l}\text { Retrato (portrait: } 3 \text { parts, } 66 \text { chapters } \\
\text { or 'mamotretos') }\end{array}$ & Narration, monologue and dialogue \\
\hline Apology & Argumentative text \\
\hline Table or explicit & Exposition \\
\hline Epistle from the author & Formal epistle \\
\hline Letter of excommunication (verse) & Formal epistle \\
\hline Epistle from Loçana & Informal epistle \\
\hline Epilogue & Informal epistle \\
\hline
\end{tabular}

Table 3. Groups of discourse varieties

\begin{tabular}{|c|c|}
\hline GROUPS OF DISCOURSE VARIETIES & DISCOURSE VARIETIES \\
\hline \multirow{2}{*}{ 1) Oral group (communicative immediacy) } & Prototypical oral interaction \\
\hline & Oral narration \\
\hline \multirow{4}{*}{$\begin{array}{l}\text { 2) Intermediate oral group (close to commu- } \\
\text { nicative immediacy) }\end{array}$} & Argumentative dialogue \\
\hline & Expositive dialogue \\
\hline & Narrative dialogue \\
\hline & Oral reproduction of reported speech \\
\hline \multirow{4}{*}{$\begin{array}{l}\text { 3) Intermediate written group (close to } \\
\text { communicative distance) }\end{array}$} & Aside \\
\hline & Monologue \\
\hline & Informal epistle \\
\hline & Formal epistle \\
\hline \multirow{4}{*}{ 4) Written group (communicative distance) } & Narrative writing - titles \\
\hline & Narrative writing \\
\hline & Expository writing \\
\hline & Argumentative writing \\
\hline
\end{tabular}

h) degree of dialogicity; i) degree of spontaneity; j) degree of topic fixedness. This enables their positions in the conceptional continuum to be determined, and four groups of discourse varieties, according to their affinity to the communicative immediacy or distance, to be established: oral group, intermediate oral group, intermediate written group and written group (Table 3).

In order to decide the immediate or distant nature of the linguistic features studied, its frequency and distribution in the various discourse types has been analysed. It is shown below in charts. The linguistic features that are more 
frequent in the oral groups and, especially, in the sequences of the text that I have classified as 'prototypical oral interaction', would be expected to be typical of the communicative immediacy. Nevertheless, to assess with more precision the degree of orality incorporated in the RLA, it has been necessary to compare Delicado's book with other texts of the same period representative of the spoken graphic model. In particular, my corpus includes private letters sent from Hispanic America (edited by Fernández Alcaide [2009]), inquisitorial acts (studied by Eberenz and de la Torre [2003]), Sephardic Responsa (edited by Benaim [2011]) and literary texts such as plays (Torres Naharro's Soldadesca and Tinellaria and the anonymous Comedia Thebayda) or dialogued novels Tragicomedia de Calisto y Melibea by Fernando de Rojas, Segunda Celestina by Feliciano de Silva). Thanks to the Corpus Diacrónico del Español (CORDE n. d.), it has been possible to consult other early modern Spanish texts. Furthermore, I have taken into account Golden Age Spanish works containing linguistic information (Diálolgo de la Lengua by Juan de Valdés), grammars and dictionaries - available through the Nuevo Tesoro Lexicográfico de la Lengua Española (NTLLE n. d.), as well as recent studies on orality (especially studies on medieval and early modern Spanish texts. ${ }^{15}$

Following Oesterreicher's methodological suggestions (2004a), the universal and historical features of sixteenth-century Spanish, on all linguistic levels (phonic, morphosyntactic, lexical-semantic and pragmatic-discourse levels), have been analysed.

The RLA's characters have been classified according to geographical and social background; likewise, communicative situations have been classified as public, private and intimate communication. Situations where anger occurs with different insults used, and sexual relationships, are especially relevant. The RLA allows an analysis of the language used during sexual intercourse, which is exceptional in early modern Europe. It is also significant that women are portrayed as characters who enjoy talking whilst practising sex, as most of the dialogues in these situations belong to female characters, especially Lozana. This means that women's voices and words used in their sexual relationships are heard. When classifying characters, the following social variables were considered: social stratum (state: nobility, clergy, non-privileged; economic level: poor, rich; educational level: learned, literate, illiterate; social prestige: prestigious, non-prestigious; occupation); geographical origin; age (old, adult, young, child); gender (woman, man), ethnic group (white, black); and religion (Jewish or New Christian, Old Christian, Moorish). Historical sociolinguistics methodology has been used to study diatopic (geographical), diastratic (social) and diaphasic (contextual) variants. This methodology is suited to study a literary text whose author attempts to typify his characters (who are the informants) according to their geographical or social background and different situations from a linguistic viewpoint. ${ }^{16}$ tain 2006.

16 See Medina Morales 2005a for a variational analysis of a corpus of Golden Age Spanish picaresque novels, based on a historical sociolinguistics methodology. 
Having classified discourse types, characters and communicative situations, a linguistic study has been performed. Two editions (semi-diplomatic and critical editions), transcribed according to philological criteria, have been created for the present study. Both are based on the facsimile edition (Pérez Gómez 1950) of the only surviving antique copy of the RLA. The semi-diplomatic edition (Díaz-Bravo 2010a: 409-518), which keeps the settings of spaces/ word-union of the original text, has been used for the study of medial orality. The critical edition ${ }^{17}$ (DíazBravo 2010a: 518-628), with the support of some computer programs for automatic analysis, has been essential for the study of conceptional orality. ${ }^{18}$

Finally, to support the hypothesis regarding medial orality, it is of considerable importance to take into account the communicative space in which the reception of the work took place and to analyse the internal linguistic self-awareness of the author on the phonic level. In addition, other works printed in Venice in the same years as the RLA (including Delicado's editions of Spanish literary works and other books printed by Nicolini de Sabio) have been consulted in several Italian libraries. ${ }^{19}$ I have verified that the union of words (see below 4.2) found in the RLA does not exist in those books, nor does it exist in the corpus of literary sources mentioned above (such as Torres Naharros' plays or Feliciano de Silva's Segunda Celestina).

\section{Medial orality. Writing in support of the voice}

The purpose of the original word divisions, as well as the selection of some contextual graphemes with a possible phonetic value $(-u-[\beta] / v-[b])$, was to help Italians to read this Spanish literary text aloud in public (Díaz-Bravo 2019a: 9-11). In other words, the lack of space between words corresponds to the absence of linguistic pauses; likewise, the selection of contextual letters may be conditioned by its phonetic value ( $v$ - plosive $[\mathrm{b}]$ and $-u$ - approximate $[\beta])$. This graphic configuration of the text should facilitate a correct reading of the text to those possible Italian 'letores-audientes' ['readers-listeners'] (Delicado 1530?: 53v).

\subsection{The use of contextual letters with possible phonetic value $(-u-[\beta] / v$ - $[b])$}

Regardless of its value as a consonant /v/ or a vowel / $\mathrm{u} /$ (as proposed by Nebrija [1492]), there is a contextual distribution of the letters $u$ and $v$ in the RLA. This was a usual distribution in sixteenth-century press. It is well known that the

17 A revised and enhanced version of this critical edition has been recently published online (Díaz-Bravo and Vaamonde 2019). Its main goal is to allow for linguistic research, through the combination of two methodological approaches: a philological and a corpus linguistics approach.

18 I have used the following computer programs, developed at the Institute of Computational Linguistics of Pisa: COR (concordances program), DBT (Textual Database), AyDA and CLE (lemmatisers and PoS taggers).

19 National Library of Florence, Marciana National Library of Venice and Scuola Normale Library of Pisa. 
medieval distinction between the voiced plosive bilabial / b/ and the voiced fricative labiodental /v/ was lost in early modern Spanish, in favour of the former. The differences in the manner of articulation have a phonetic nature after medieval Spanish: the plosive $[\mathrm{b}]$ is used in strong contexts, while the fricative $[\beta]$ is used in weak contexts. Both phonetic variants are represented in the RLA via the contextual letters $u$ and $v$ :

- $-u$ - represents the approximate variant [ $\beta]$, in intervocalic contexts.

- $v$ - represents the plosive variant [b], in initial position of a phonic group (i.e., in absolute initial position or after a pause), instead of at the beginning of a word (as proposed by Nebrija (1492), and as commonly used in sixteenthcentury press).

As the phonetic contextual distinction between $[\beta]$ and $[\mathrm{b}]$ does not exist in Italian, the contextual distribution of the letters $-u$ - and $v$-could assist Italian speakers in choosing and pronouncing the correct variant while reading aloud.

\subsection{Non-accidental union of words in the configuration of the text}

Apart from groups of words that are usually written together in early modern Spanish press (such as: alos, enel, delas, eneste, elqual, ami, alos, aqueste, aquesas, estotro, deste, dese, dello), many words in the RLA are written together, imitating the way they should be read aloud. Delicado indicates which words should be read without a break. The following reasons support my hypothesis:

- These words, very often, form a sirrema (for example: estasemana, asumadre, quelloráuades). ${ }^{20}$ The lack of space between words corresponds to the absence of linguistic pauses - which cannot exist within a sirrema - in reading aloud.

- Most of the words are linked because of the need for a stress, as what happens in the spoken language (for example, the union of non-stressed and stressed words sintocino, acomer, paraseruir).

- The length of the words which are written together never exceeds eight syllables, corresponding to the extension of a Spanish phonic group (cf. Navarro Tomás 1948: 46; Quilis 1999: 418) (for example: auíadesenbiado).

This is coherent if the importance given by Delicado to pronunciation is borne in mind: the small treatises added to his Venetian editions of Spanish literature bestsellers addressed to an Italian audience should be considered as instructions for correct pronunciation in Spanish. The selection of contextual letters may be conditioned by its phonetic value ( $v$ - occlusive $[b]$ and $-u$ - fricative $[\beta])$. This selection should enable a correct and clearer reading (aloud) of his work to those possible Italian 'letores-audientes' (Delicado 1530?: 53v), who would not be able to distinguish between fricative and plosive variants. This way, pauses and prosodic indications would be understood by the audience.

20 A sirrema is a group of two or more words which are part of a grammatical, tonal and meaning unit; it cannot be smaller than a word or bigger than a sentence (Quilis 1999: 372). 
This theory is reinforced by the book being printed to remedy Delicado's poverty after the sack of Rome, meaning he had to publish a cheap edition of his book. While saving spaces and, thus, pages, he was not only saving money but also helping his readers.

\section{Conceptional orality. The mimesis of the spoken language}

My hypothesis about conceptional orality links to mimesis of the spoken language. ${ }^{21}$ This is a literary resource used by Delicado to present Lozana and other characters in the book, as well as communicative situations, from a linguistic point of view. ${ }^{22}$ In other words, he uses features of the spoken language to portray characters according to their geographical or social backgrounds (through diatopic and diastratic variants respectively) and communicative situations (through diaphasic variants, i.e., contextual variation according to more formal or informal settings). Furthermore, he imitates the mechanisms and strategies of oral dialogicity (the universal features of the spoken language), mainly in the parts of the text classified as the 'prototypical oral interaction'.

\subsection{Universal features of sixteenth-century spoken Spanish}

On the phonic level, sinalefas and elisions (e.g., dagua, leran, suplicos) and onomatopeias (tif taf 'knocking at the door', çape 'frighten away the cats', hi hi 'laugh') are employed in the RLA. These resources are stereotypical features used to imitate spoken language in other early modern Spanish literary texts. For example, Torres Naharro (1517) uses sinalefas and elisions in his Propalladia, represented in the same way as in the RLA, i.e., by removing one vowel and linking the words without any punctuation (e.g. quel, questos); while Juan de Valdés (1535?) employs a circumflex (e.g. pudiendôs) (Pountain 2001: 132). To illustrate, there are examples of the onomatopeias $h i$ hi and $t a t a^{23}$ in Feliciano de Silva's Segunda comedia de la famosa Celestina (1536) and the Tragicomedia de Calisto y Melibea (1531; 1534) (variants tha tha); and examples of çape in Tragedia de la castidad de Lucrecia by Juan Pastor (1550). ${ }^{24}$ Both sinalefas and onomatopeias are typical of the communicative immediacy, as can be observed in charts 1 and $2:^{25}$

21 See, for example, Vian Herrero 1987; 1988; Iglesias Recuero 1998; Bustos Tovar 2001; Oesterreicher 2004a.

22 Diaz Bravo (2019a: 16-22) analyses the linguistic characterization of communicative situations and characters in the RLA.

23 Tif, taf to express knocking at the door is only documented in the RLA.

24 Pastor (1990 [c. 1550: fol. AVV]), apud CORDE.

25 The number in parenthesis for each group (oral, intermediate oral, intermediate written, written) in the charts corresponds to the number of occurrences of each linguistic feature analysed. 


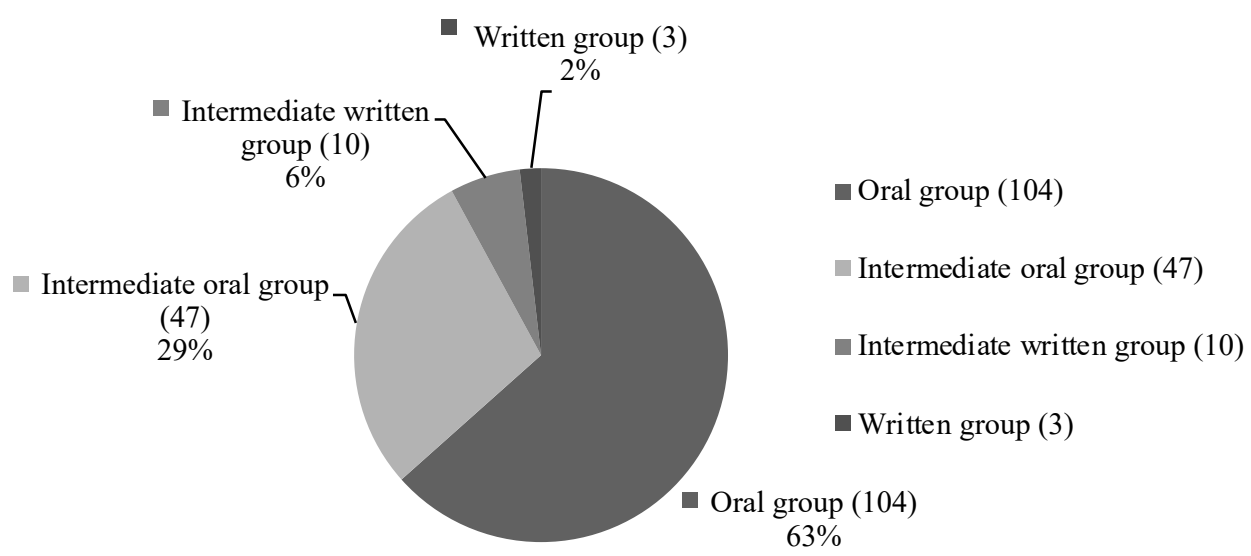

Chart 1. Sinalefas

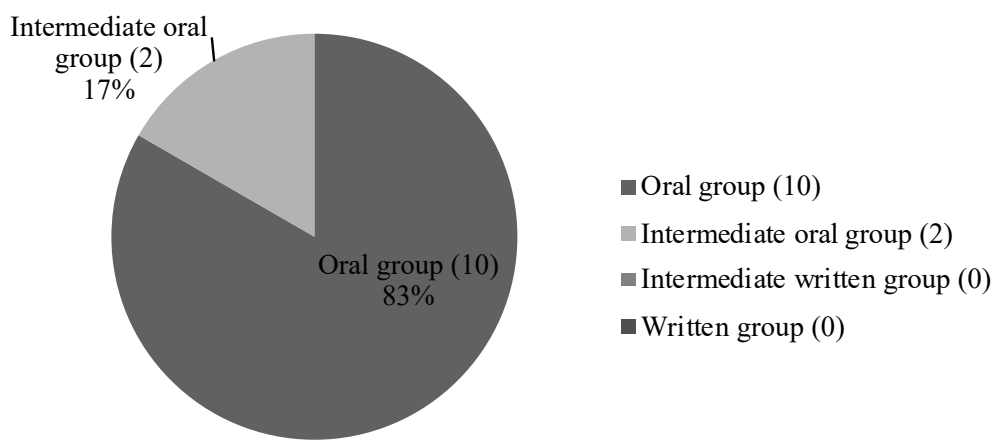

Chart 2. Onomatopeias

On the morphosyntactic level, Delicado imitates conceptional orality using repetitions (Chart 3), mostly in the prototypical oral interaction with appeals to interlocutors. Such repetitions can be the confirmation of a conviction or an agreement ('¡Ya, ya, por mi vida que lo conosco!' [Delicado 1530?: 20r]) or commands and requests expressed with imperatives (‘Aguzá, aguzá!’ [Delicado 1530?: 11v]) and deictics ('¡Allí, allí me hormiguea!' [Delicado 1530? 11v]). ${ }^{26}$ The repetitions in the latter examples, taken from Lozana's words while having sex the first night with Rampín, express emphasis.

By contrast, examples of the emphatic repetition of a quantifier, in which the interlocutor is not involved, are documented in the closest varieties to the pole of the comunicative distance in the conceptional continuum ('Cordialíssimos letores: Pienso que munchas y munchas tragedias se dirán de la entrada y salida de los soldados en Roma’ [Delicado 1530?: 54v]).

26 Other examples of repetitions are found in Torres Naharro's Propalladia (1517), for instance: 'Agora, agora los vi' (Tinellaria, jornada II). 


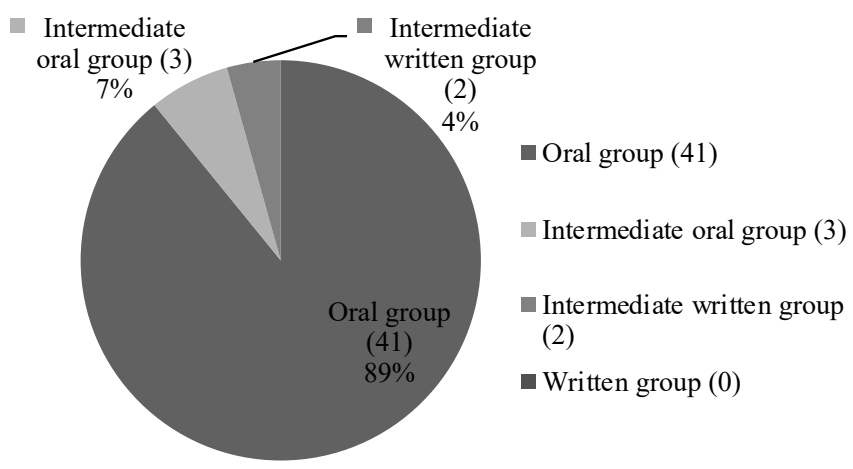

Chart 3. Repetitions

On the lexical-semantic level, Delicado uses spontaneous lexical creations (Chart 4), typical of daily conversations (Vigara Tauste 2005: 296). There is a remarkable display of verbal creativity in the RLA, with a high number of spontaneous lexical creations. ${ }^{27}$ Most of these are based on mechanisms of derivation and composition, and on the topic of prostitution, to name the male genital organ or to insult Rampín. Lexis made up about prostitution is applied to persons ('prostitute': tragasantos, tragacaramillos, beuedardos; 'procuress': alcagotara), but also to the 'brothel' (regagero de putas). Other spontaneous lexical creations are pejorative names for Rampín (tragatajadas, malvrde, calcotejo, chichirinbache) or expressive designations of the male sexual organ, whose augmentative suffix is related to its size (frojolón, dinguilindón, mandragulón and picaraçada). Many of these terms make reference to sex, often used as insults. ${ }^{28}$ This is the reason why they are often used to characterize communicative situations of sex or anger. Therefore, Delicado uses spontaneous lexical creations to imitate the spoken language, although with a higher frequency than in daily conversation, given that his book is a literary text.

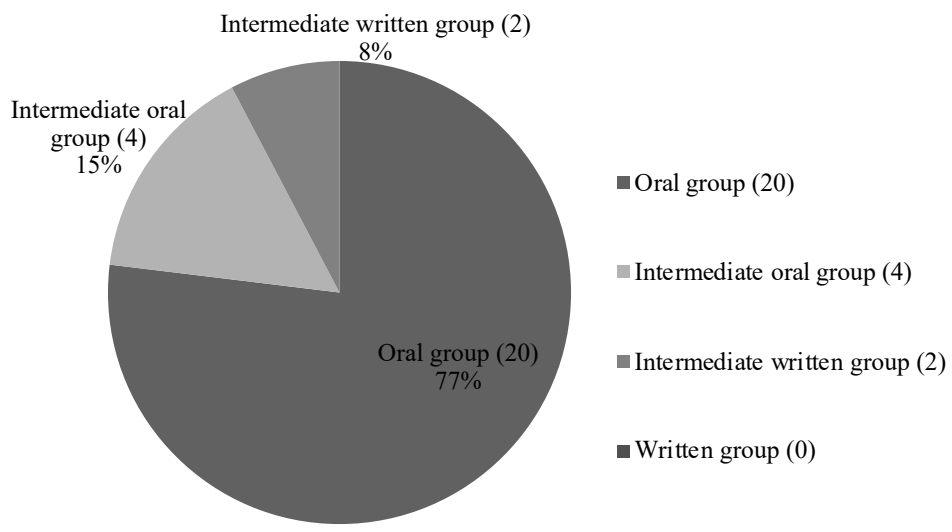

Chart 4. Spontaneous lexical creations

27 Allaigre's (2000) and Perugini's (2004) critical editions of the RLA are especially useful for an analysis of these creations, as well as for a study of words with erotic and sexual connotations (taking into account semantic fields and polysemy).

28 Elena Taddia (2013) has noted that most common insults for both men and women were related to sex/ prostitution: beccofottuto, coglione (for men); ruffiana, strega, putana (for women). 
Finally, on the pragmatic-discourse level, the conversational markers bien, bueno, sí haré, mira, mirá, mire vuestra merced, mire vuestra señoría, miren vuestras mercedes and the discourse marker pues (Chart 6), frequent in the communicative immediacy, are used by Delicado to imitate the spoken language. ${ }^{29}$ The following communicative parameters are relevant to the high frequency of conversational markers (Chart 5) with direct appeals to the interlocutor: physical immediacy, degree of cooperation between participants in the conversation and degree of dialogicity.

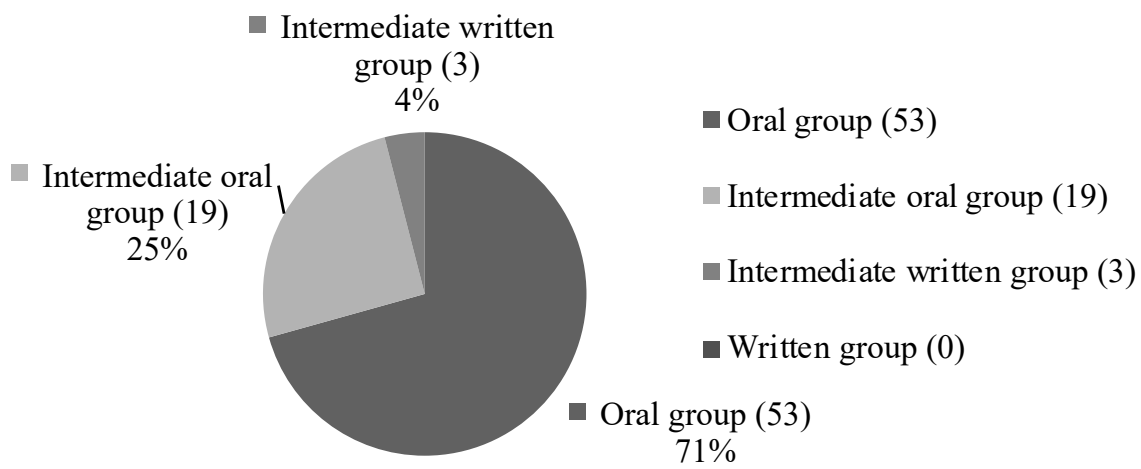

Chart 5. Conversational markers

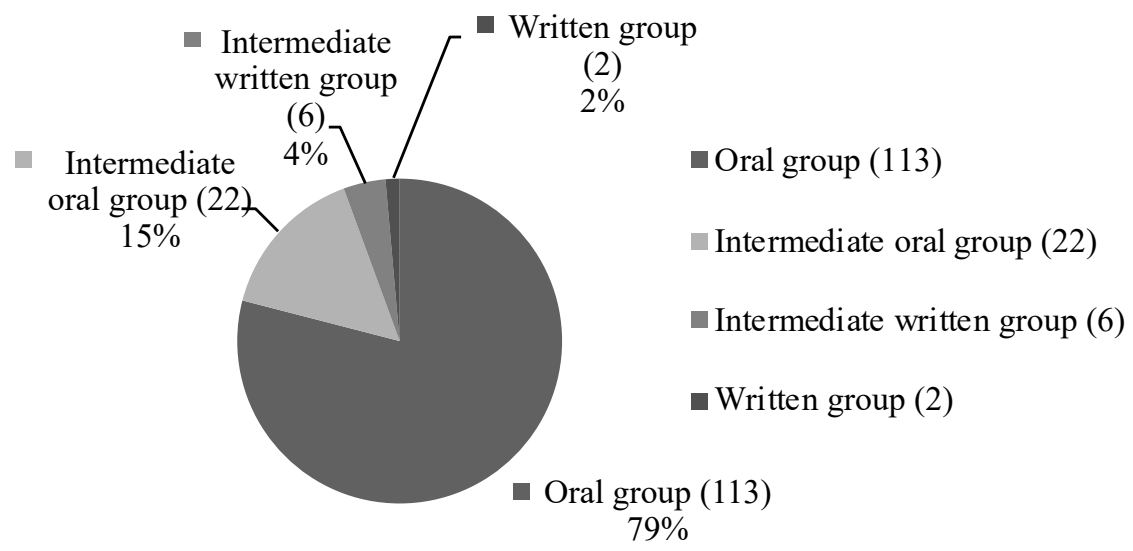

Chart 6. Discourse marker pues

5.2. Historical-language features of sixteenth-century spoken Spanish

Analysis of the author's external linguistic self-awareness, communicative space where the major part of the action happens (Rome), as well as the various types of characters in the book (from a geographical and social point of view) are relevant to the study of historical-language features of sixteenth-century spoken Spanish.

29 See Pountain 2016 for a variational analysis of discourse markers in sixteenth-century Spanish; and Díaz-Bravo and Fernández Alcaide 2018 for a contrastive analysis of the use of discourse markers in the RLA and private letters written from Hispanic America in the sixteenth century. 
On a phonic level, Delicado used features of Judeo-Spanish (Chart 7) to represent Jews in the sequences classified as prototypical oral interaction: the irregular diphthongs in quienze, quieréys, cueréys and the palatalization-vocalisation of /-s/ (in the position of coda) in moyca and moycada. ${ }^{30}$ These linguistic features have been documented in sixteenth-century Judeo-Spanish sources (Benaim 2011) and in a poem from the Judeo-Spanish oral tradition (Scherer 2009).

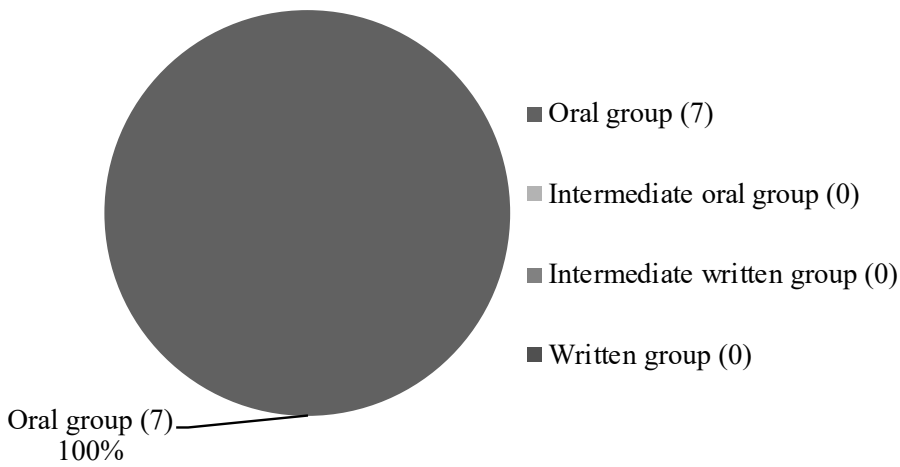

Chart 7. Vocalism: Features of Judeo-Spanish

Nasal epenthesis in concho, nanbo, truncha, nientos, hinzo, çienga, nunblo, lingar, especially frequent in the quantifier muncho, are typical of Andalusian speech. Therefore, it could have been used by the author to characterize Andalusians. However, it is a feature typical of Delicado as an Andalusian and not used to characterize Andalusian speech, since there is a similar distribution in all discourse types groups (Chart 8).

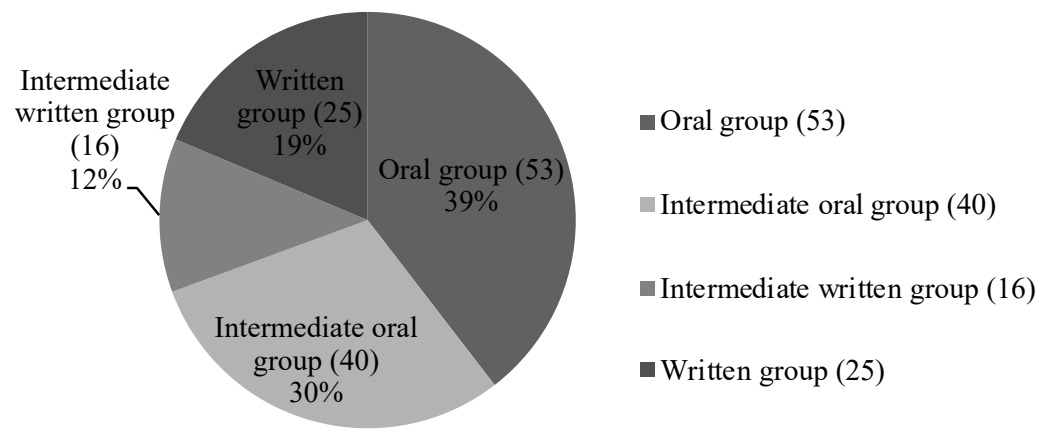

Chart 8. Nasal epenthesis

The replacement of [-bwé-] by [-gwé-] (agüelo/a/as) (Chart 9) is a feature typical of communicative immediacy. It is documented in the sixteenth century in texts characterized by linguistic immediacy: private correspondence (Fernández Alcaide 2009) and Inquisitorial acts (Eberenz and de la Torre 2003). It is used by Delicado in the oral and intermediate oral groups of discourses, mainly in private communicative situations when there is an emotional link between participants.

Modern editors have usually corrected these variants. 


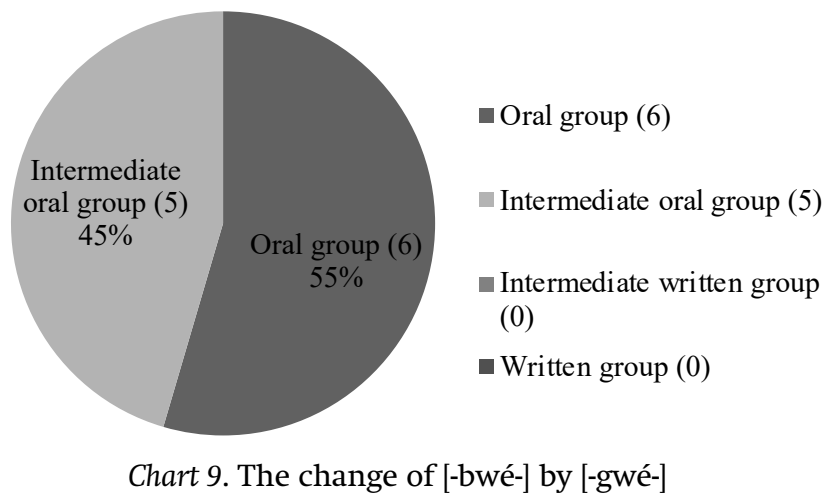

In order to characterize the black female servant, two stereotypical features (Chart 10), frequently used in that period for comic effect, occur in the RLA:1) the palatalization of the alveolar consonant $/ \mathrm{s} /$ in basic words such as xeñora [lady] or $x i$ [yes]; 2) the use of the infinitive instead of its correspondent conjugated verbal forms. For example: 'ESCLAUA: Xeñora llamar. LOÇANA: ¡O, qué linda tez de negra! ¿Cómo llamar tú? ¿Conba? ESCLAUA: No, llamar Penda de xeñora. LOÇANA: Yo dar a ti cosa bona. ESCLAUA: Xeñora, xí. Venir, venir, xeñora dezir venir' (Delicado 1530?: 19r). ${ }^{31}$ Both features are documented in contemporary literary texts (e.g., Comedia Tesorina). ${ }^{32}$ The latter phenomenon, of a morphosyntactic nature, is also documented in Inquisitorial acts (Eberenz and de la Torre 2003: 73-74). These features always appear in prototypical oral interactions.

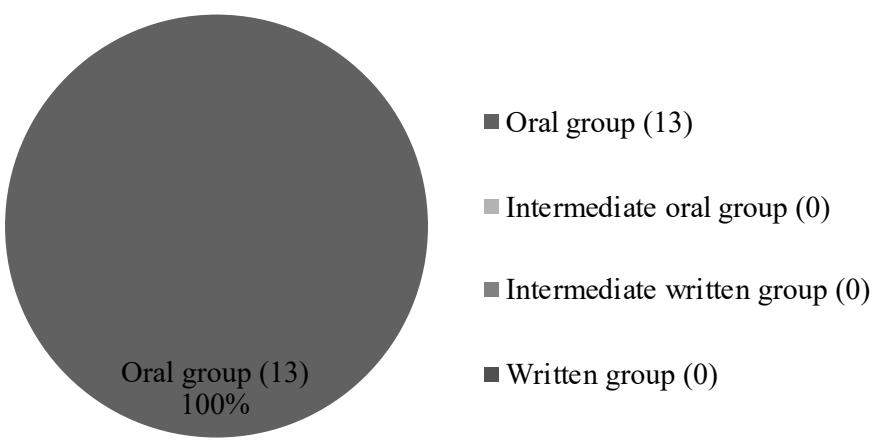

Chart 10. Stereotypical features of the speech of black characters

Another morphosyntactic feature that has been analysed is the verbal desinence $i e$ in the conditional and, especially, in the indicative imperfect (Chart 11). At first, it was thought that this was an archaism and that, as such, it did not belong to a refined style (cf. Oesterreicher 2004a: 736; Medina Morales 2005a: 234-36). However, after analysing it in Delicado's entire work and comparing the results with other studies (González Ollé 2000; Eberenz and de la Torre 2003:

31 The linguistic accommodation that Lozana shows when talking to her conversational partner, using infinitives, is of particular interest.

32 Huete (1993 [c. 1528]: 117-18), apud CORDE. 
177), it is possible to conclude that the dissemination of this ending was probably wider in the sixteenth-century than is usually thought. It was connected with the speech of Toledo and, possibly with Andalusian speech (the best diatopic varieties, according to our author). For this reason, this ending is used in the prototypical oral interaction to characterize some Andalusian women and, especially, learned characters (representative of the alter ego of the author). It is also used in the group of communicative distance discourse types.

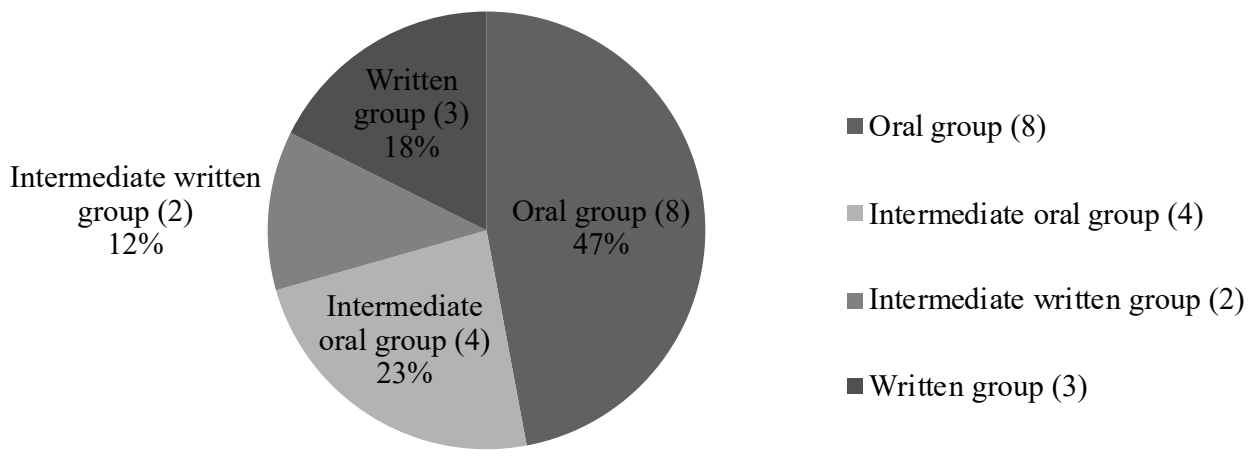

Chart 11. Imperfect and conditional desinences ie

On a lexical-semantic level, the study of the vocabulary related to the topics of prostitution and sexual anatomy has provided useful data to the analysis of diatopic, diastratic and diaphasic variants related to communicative immediacy. ${ }^{33}$ In addition, its semantic precision is outstanding.

Many words are used to denote 'prostitute'. There are some hyponyms of 'prostitute': cortesana [prostitute of higher level], ramera [honest prostitute], and andorra [prostitute or street-walker]. These words belong to the standard language. In addition, the learned word meretriz (from Latin MERĚTRIX) is used to typify learned characters. The Italianisms putana and escanfarda (translated as 'puta, fregona, cachonda' in Casas (1988 [1570], s.v. scanfarda) - linguistic variants related to communicative immediacy - are used to portray not only Italian characters but also Spaniards who have been living in Rome for some time. Other linguistic variants related to communicative immediacy are the following: the lower diastratic variant bagasa (defined as 'prostituta de baja calidad' by Alonso Hernández (1976, s.v.) - typical of lower social classes - and the lower diaphasic variants mundaria ('prostitute', derives from the word mundo, see Díaz-Bravo 2010b: 178) - and puta - typical of situations of anger. Due to the existence of a variational chain (Koch and Oesterreicher 2007: 39), the words escanfarda and bagasa can also function as diaphasic variants. All the mentioned linguistic variants related to communicative immediacy are more frequent in the oral groups of discourses (Chart 12):

33 See Díaz-Bravo's studies on prostitution (2010b) and sexual-anatomic (2012) vocabulary in sixteenth-century Spanish. 


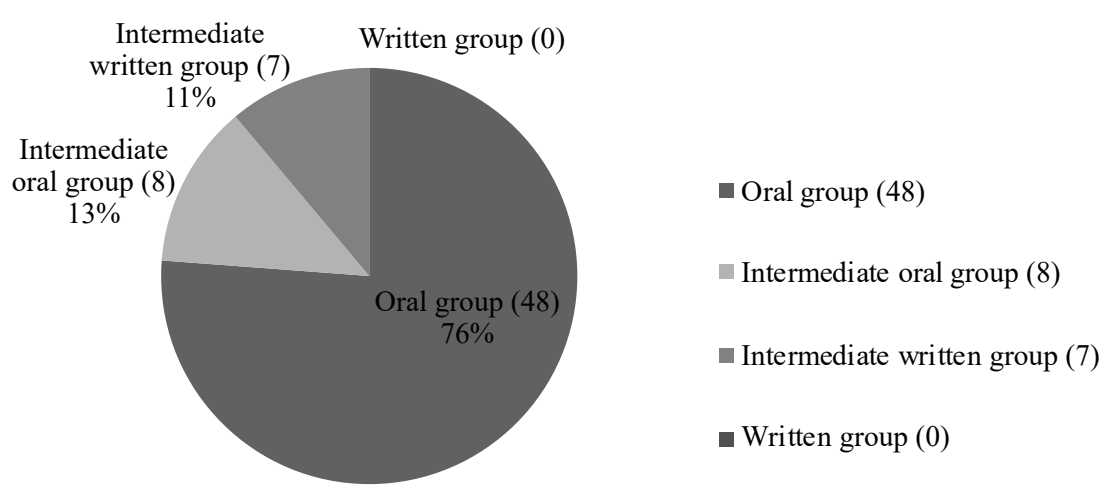

Chart 12. 'Prostitutes': Italianisms, lower diastratic and diaphasic variants

Different words denote alcahueta [procuress] and alcahuete [pimp]. Some terms (such as trujamana 'eloquent procuress') are hyponyms. There are words of the standard language (alcagüeta, trujamana and rufián) and Italianisms (tabaquina and rufiana). The latter - the most relevant for the study of conceptional orality - are only found in the oral and intermediate oral groups (Chart 13).

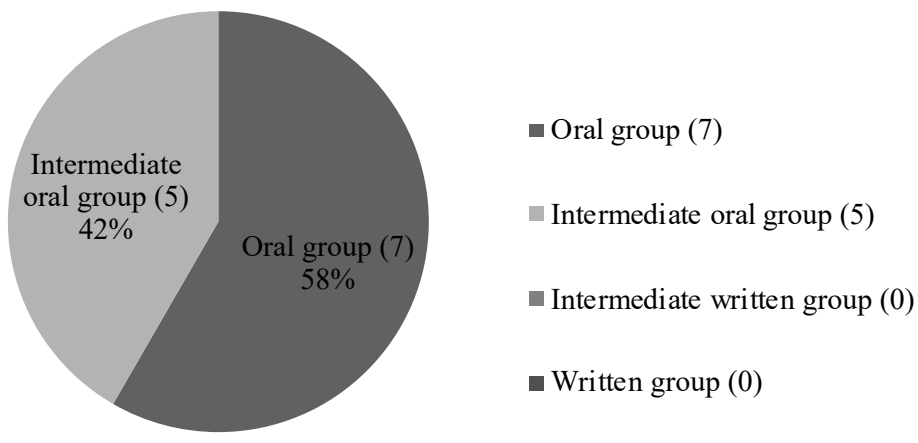

Chart 13. 'Procuress': Italianisms

With reference to words used to label the 'brothel', the hyponyms estufa [public bath used as brothel] and publique [higher brothel] (due to the prestige of the famous Publich of Valencia) have been documented. ${ }^{34}$ The words burdel, mancebía and putería, which are synonyms of 'brothel', were standard forms. The Catalanism burdell is used in a Catalan dialogue by the Valencian woman Sogorbesa.

In sum, the prostitution terms which are close to communicative immediacy (Chart 14) are mostly words from other languages (Italian: putana, escanfarda, rufiana, tabaquina; Catalan: burdell) and linguistic variants used by the characters from the lowest classes (bagasa) or in some informal communicative situations where they frequently become insults (puta, mundaria). ${ }^{35}$ Moreover, the words

34 The term publique meaning 'brothel' has also been documented in the anonymous Comedia Thebayda (Canet 2003: 267).

35 Elena Taddia (2013) has found examples of ruffiana and putana used as insults in criminal archives in early modern Italy. 
from other languages and the lower diastratic variant bagasa function in the same way as the lower diaphasic variants. Linguistic variants close to communicative immediacy are more frequent in the prototypical oral interaction, as can be observed in this chart:

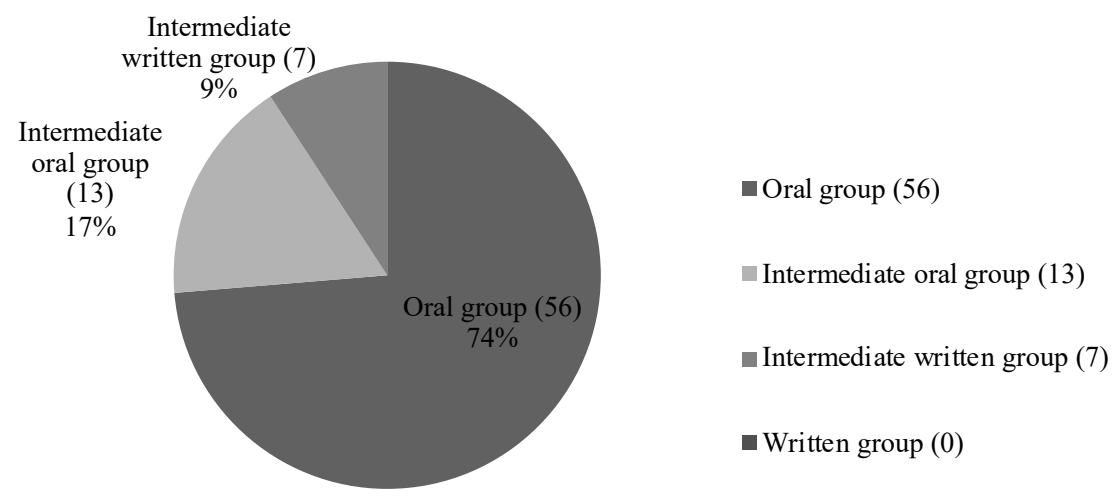

Chart 14. Prostitution: Variants related to communicative immediacy

It has also been possible to research some linguistic variants close to the communicative immediacy in the semantic field of sex and anatomy (Chart 15). Besides the technical term madre, most of the words are typical of the standard language (natura, pendejo, compañón, teta and pezón). Nonetheless, there are examples of a number of lower diastratic and diaphasic variants (coño, papo [female sexual organ], cojón [testicle], hoder [to have sexual relationships]). Being the latter taboos, they are more frequent in the oral and intermediate oral groups:

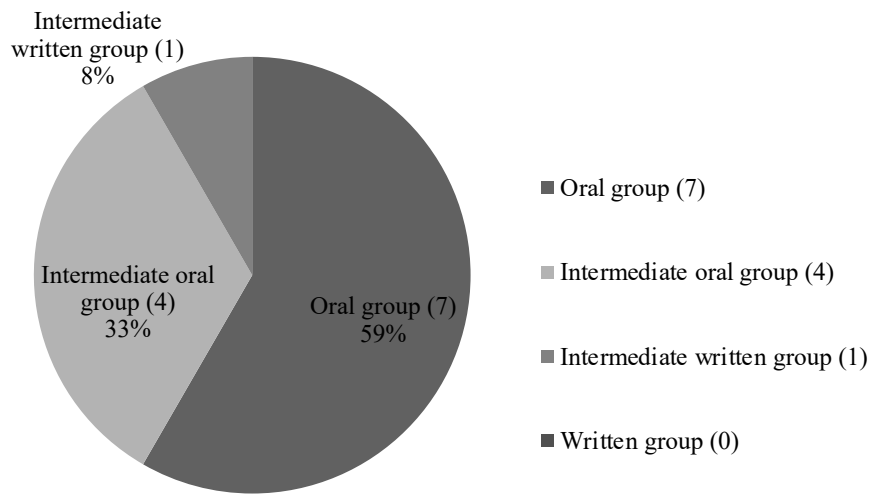

Chart 15. Sexual-anatomic vocabulary: Variants related to communicative immediacy

On a pragmatic-discourse level, the tripartite system of address typical of sixteenth-century Spanish (tú: used to address an inferior interlocutor; vos: polysemic form of address, with values between tú and vuestra merçed; vuestra merçed: respectful form of address) is represented in the RLA. It is one of the linguistic features which is best used by the author in order to portray characters and communicative situations. The most frequent form of address in the work is the polisemic pronoun vos. It is close to vuestra merced and tú. It could be 
used in formal situations and in order to show respect, but it frequently needed to be reinforced by a nominal form of address, such as señor, señora. In addition, despite being close to the expressive values of tú, in that period it had not yet reached the devaluation of the seventeenth century. The pronoun vos is typical of intimate situations. For example, Loçana uses vos with her customers while having sexual relations; however, the form of address used while negotiating the payment is the more deferential vuestra merced. Likewise, she addresses her lover Rampín as vos in intimate situations, but changes to tú in front of other characters, when he has the role of her servant. Moreover linguistic features pertaining to male chauvinism have been found among husbands and wives, and mothers and sons/ daughters: male characters are addressed by vos; on the other hand, feminine characters are addressed by tú (asymmetric form of address used to talk to an inferior person). Forms of address are more frequent in the prototypical oral interaction. In addition, the lower degree of dialogicity in epistles (vocatives and openings) can be perceived in Chart 16:

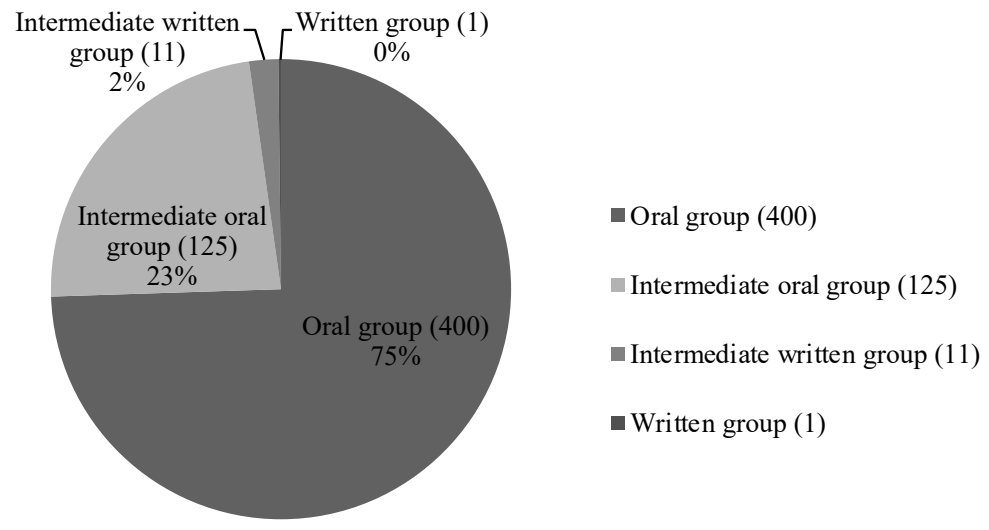

Chart 16. Forms of address: tú, vos, vuestra merçed

\section{Conclusions}

After the linguistic analysis of oral features in the Retrato de la Loçana andaluza, it is possible to answer the research question posed at the beginning of this study:

- What kinds of orality are found? There are features of both conceptional and medial orality in this literary work, which makes it an excellent source to study past orality.

- In which discourse types is orality found? Discourse types are only relevant in relation to the conceptional orality: those features that are closer to communicative immediacy are more frequent in the oral group of discourse types (especially in the prototypical oral interaction); the number of occurrences decreases as we approach the discourse group of the communicative distance.

- What features are chosen by the author to represent orality? It is necessary to distinguish between medial and conceptional orality again. The features 
selected by Delicado to represent medial orality (graphic elements used to help his readers) belong to the phonic level: contextual letters with possible phonetic value and, mainly, the union and division of words that help to mark the pauses and the prosody of the text. The features chosen to represent the conceptional orality are the universal and historical-language features of the Spanish spoken in the sixteenth century on all linguistic levels.

The answer to the last question (what was the purpose of using this orality?) is of the utmost importance, since it provides coherence to the hypotheses. On the one hand, the representation of the features of medial orality in the graphic configuration of the text, with implications at a phonic level, had the purpose of helping the readers-listeners, 'letores-audientes', read aloud this literary work correctly. Since this audience included not only Spaniards but also Italians, these would better understand the text and, consequently, enjoy it more. On the other hand, the author uses the features of conceptional orality to portray characters that live in the multilingual and multicultural city of Rome prior to the famous sack. To conclude, it can be confirmed that the Retrato de la Loçana andaluza is an exceptional example of the mimesis of the spoken language of sixteenth-century Spanish. This mimesis is achieved by using universal features of the spoken language, multilingualism, and language interferences. Regarding the historicallanguage features of sixteenth-century Spanish, Delicado uses diatopic, diastratic, or diaphasic variants, in order to typify his characters (according to their geographical or social origins) and communicative situations. Furthermore, he uses stereotypical features and common characteristics of an Andalusian speaker.

Finally, a few observations should be considered. There is difficulty in undertaking a study of the orality of a sixteenth-century written text, since the phonic medium is not accessible through recordings. In addition, the Retrato de la Loçana andaluza is a complex literary text, interpreted in different ways by scholars. Due to the existence of historical-linguistic boundaries, the only way to access the orality from the past is through written records, in writing characterized by linguistic immediacy. Consequently, conclusions must be drawn cautiously. A literary author controls and selects the oral features s/he wishes to represent.

With these provisos, it is possible to state that Francisco Delicado shows us a portrait of a prostitute, Loçana, an Andalusian like himself. At the same time, there is a portrait of Rome, and the essential element of this portrait is the spoken language. This way Delicado created a vivid painting of Rome that, in a very special way, retained the multicultural voices of its streets, including Loçana's voice. This portrait contains what his author had seen and heard, and written afterwards, aware that his work would be read aloud in public. While reading this book, we can almost hear - and it is one of its greatest achievements - the echo of those multiple vanished voices of the Spanish spoken in Italy in the sixteenth century. 


\section{Works cited}

\section{Primary sources}

Benaim, Annette (ed.), 2011. Sixteenth-Century Judeo Spanish Testimonies: An Edition of Eighty-four Testimonies from the Sephardic Responsa in the Ottoman Empire (Leiden: Brill).

Canet Vallés, José Luis (ed.), 2003. La comedia Thebayda (Salamanca: Universidad de Salamanca).

Casas, Cristóbal de las, 1988 [1570]. Vocabulario de las dos lenguas toscana y castellana (Seville), ed. A. David Kossof (Madrid: Ediciones Istmo).

Covarrubias, Sebastián de, 1611. Tesoro de la lengua castellana o española, reproducido a partir del ejemplar de la Biblioteca de la Real Academia Española, O-73, Luis Sánchez, Madrid (see NTLLE).

CORDE (Corpus Diacrónico del Español). Real Academia Española. Available at: <http://corpus. rae.es/cordenet.html> [accessed 3 November 2019].

Delicado, Francisco (ed.), 1531. Tragicomedia de Calisto y Melibea by Fernando de Rojas (Venice: Juan Batista Pedrezano). Biblioteca Nacional de España R-12345.

- (ed.), 1533. Los quatro libros de Amadís de Gaula by Garci Rodríguez de Montalvo (Venice: Juan Antonio de Sabia impressor de libros, a las espesas de Juan Batista Pedrezano). Biblioteca Nacional de España R-8494. Available at: <http://bdh-rd.bne.es/viewer.vm?id=0000007144\& page $=1>$ [accessed 4 December 2019].

- (ed.), 1534a. Tragicomedia de Calisto y Melibea by Fernando de Rojas (Venice: Estephano da Sabio). Biblioteca Nacional de España R-15030.

- (ed.), 1534b. Los tres libros del muy esforçado caballero Pimaleón et Polendos su hermano, hijos del Emperador Palmerín de Oliua, Anonymous (Venice: Iuan Antonio de Nicolini de Sabio, a las espesas de Zuan Batista Pedreçan, mercader de libros). Biblioteca Nacional de España R-12100. Available at: $<$ http://bdh-rd.bne.es/viewer.vm?id=0000151368\&page $=1>$ accessed 4 December 2019].

[Delicado, Francisco], 2019 [1530?]. Retrato de la Loçana andaluza (Venice: publisher unknown), in Lozana Digital, ed. Rocío Díaz-Bravo and Gael Vaamonde (Granada: Universidad de Granada). Available at: <http://corpora.ugr.es/lozana/index.php?action=home> [accessed 4 December 2019].

Fernández Alcaide, Marta, 2009. Cartas de particulares en Indias del siglo XVI: edición y estudio discursivo (Madrid/ Frankfurt am Main: Iberoamericana/ Vervuert).

Huete, Jaime de, 1993 [c. 1528]. Comedia Tesorina, ed. Ángel Pérez Priego (Valencia: UNED SevilleValencia).

Nebrija, Antonio de, 1492. Gramática de la lengua castellana. Facsimile edition, Instituto de Cooperación Iberoamericana. (Madrid: Ediciones de Cultura Hispánica).

NTLLE, n. d. Nuevo Tesoro Lexicográfico de la Lengua Española. Real Academia Española. (Madrid: Espasa Calpe). Available as DVD and at: <http://ntlle.rae.es/ntlle/SrvltGUILoginNtlle> [accessed 3 November 2019].

Pastor, Juan, 1999 [c. 1550]. Tragedia de la castidad de Lucrecia, ed. Amy Sevcik (Valencia: Lemir).

Pérez Gómez, Antonio (ed.), 1950. Retrato de la Loçana andaluza by Francisco Delicado. Facsimile edition (Valencia: Talleres de Tipografía Moderna). Available at: <http://www.cervantesvirtual. com/obra-visor/retrato-de-la-lozana-andaluza--0/html/ffcfbd8a-82b1-11df-acc7-002185ce6064. htm> [accessed 4 December 2019].

Scherer, Rebecca, 2009. 'En La Ora De Neila El Sheytan Sale Tepdil', Los muestros: La boz de loz sefaradim. Revista de Judeo-Español, 76. Available at: Available at: <http://sefarad.org/lm/076/ html/page7.html> [accessed 4 December 2019].

Silva, Feliciano de, 1536. Segunda comedia de la famosa Celestina (Venice: Stephano da Sabio). Biblioteca Nacional de España R-15030.

Torres Naharro, Bartolomé de, 1517. Propalladia (Naples, Ioan Pasqueto de Sallo). Biblioteca Nacional de España R/8079.

Valdés, Juan de, 2014 [1535?], Diálogo de la lengua, ed. Kormi Anipa (Cambridge: Modern Humanities Research Association, Critical Texts, 38). 


\section{Secondary sources}

Allaigre, Claude (ed.), 2000 [1985]. La Lozana andaluza, ed. Claude Allaigre (Madrid: Cátedra).

- , 2004. 'Las "ciento e veinte e cinco personas que hablan" del Retrato de la Lozana andaluza', in Siglos Dorados, Homenaje a Agustín Redondo, ed. Pierre Civil (Madrid: Editorial Castalia), I, pp. 15-31.

Alonso Hernández, José Luis, 1976. Léxico del marginalismo del Siglo de Oro (Salamanca: Universidad de Salamanca).

Anipa, Kormi, 2001. A Critical Examination of Linguistic Variation in Golden-Age Spanish (New York and Oxford: Peter Lang).

Asensio, Eugenio, 1961. 'Juan de Valdés contra Delicado. Fondo de una polémica', Studia Philologica I, Homenaje a Dámaso Alonso (Madrid: Gredos), pp. 101-13.

Ávila, Ana, 2008. Pietro Aretino: Los modi y los sonetos lujuriosos (Madrid: Siruela).

Bognolo, Anna, 2012. 'El libro español en Venecia en el siglo XVI', in Rumbos del hispanismo en el umbral del Cincuentenario de la AIH, III, Siglo de Oro (prosa y poesía), ed. María Luisa Cerrón Puga, coord. Patrizia Botta (Roma: Bagatto Libri), pp. 243-58.

Bubnova, Tatiana, 1987. F. Delicado puesto en diálogo: las claves bajtinianas de La Lozana andaluza (Mexico City: Universidad Autónoma de México).

- , 2001. 'Valdés y Delicado: ¿un diálogo de la lengua?', Anuario de Letras 39, Homenaje a Margit Frenk, pp. 89-108.

Bustos Tovar, José Jesús de, 2001. 'Algunos tipos de diálogo en el español del siglo XVI', in Lengua, discurso, texto (I Simposio Internacional de Análisis del Discurso), ed. José Jesús de Bustos Tovar, Patrick Charaudeau, José Luis Girón Alconchel, Silvia Iglesias Recuero and Covadonga López Alonso (Madrid: Visor Libros), II, pp. 1515-30.

Calderón Campos, Miguel, 2015. El español del reino de Granada en sus documentos (1492-1883). Oralidad y escritura (Bern: Peter Lang).

Cohen, Thomas, and Lesley K. Twomey (eds), 2015. Spoken Word and Social Practice: Orality in Europe (1400-1700). Medieval and Renaissance Authors and Texts, 14. (Leiden: Brill).

Díaz-Bravo, Rocío, 2010a. Estudio de la oralidad en el «Retrato de la Loçana andaluza» (Roma, 1524), $\mathrm{PhD}$ Thesis (Málaga: Universidad de Málaga). Available as CD-ROM and at: <https://riuma.uma.es/ xmlui/handle/10630/4575> [accessed 4 December 2019].

-, 2010b. 'Glosario de voces de la prostitución en el siglo XVI', in Los diccionarios a través de la historia, ed. Antonia María Medina Guerra and Marta Concepción Ayala Castro (Málaga: Universidad de Málaga).

- , 2012. 'Estudio variacionista del léxico anatómico-sexual en el español del siglo XVI', in Avances de Lexicografía Hispánica, II, ed. Antoni Nomededeu Rull, Esther Forgas Berdet and Maria Bargalló Escrivà (Tarragona: Universitat Rovira i Virgili), II, 'Lexicografía especializada', pp. 315-28.

-, 2019a. Francisco Delicado, 'Retrato de la Loçana andaluza': Estudio y edición crítica (Cambridge: Modern Humanities Research Association, Critical Texts, 56).

- , 2019b. 'La conciencia lingüística del autor andaluz Francisco Delicado', in Quan sabias e quam maestras: Disquisiciones de lengua española, ed. Diana Esteba Ramos, Manuel Galeote, Livia C. García Aguiar, Pilar López Mora and Sara Robles Ávila (Málaga: Universidad de Málaga).

Díaz-Bravo, Rocío, and Marta Fernández Alcaide, 2018. 'La oralidad en el siglo XVI: lo literario y lo privado (I). Marcadores discursivos', Bulletin of Hispanic Studies, 95.4: 357-82.

Díaz-Bravo, Rocío and Gael Vaamonde, 2019. Lozana Digital (Granada: Universidad de Granada). Available at: <http://corpora.ugr.es/lozana/index.php?action=home> [accessed 4 December 2019].

Eberenz, Rolf, and Mariela de la Torre, 2003. 'Conversaciones estrechamente vigiladas: Interacción coloquial y español oral en las actas inquisitoriales de los siglos XV a XVII’, Hispanica Helvetica, 14. (Zaragoza: Libros Pórtico).

Frenk Alatorre, Margit, 1982 [1980]. 'Lectores y oidores. La difusión oral de la literatura en el Siglo de Oro', in Actas del VII Congreso de la Asociación Internacional de Hispanistas, Venice, 25th-30th August 1980, ed. Giuseppe Bellini (Rome: Bulzoni editore), I, pp. 101-23. 
-, 1992. 'Lectores y oidores en el Siglo de Oro', in Historia y crítica de la literatura Española. Siglos de Oro: Barroco, ed. Aurora Egido (Barcelona: Crítica), Primer Suplemento, 3.1, pp. 48-85.

Gauger, Hans-Martin, 2004. 'La conciencia lingüística en la Edad de Oro', in Historia de la lengua española, ed. Rafael Cano Aguilar (Barcelona: Ariel), pp. 681-97.

Giordano, Anna, and Cesáreo Calvo, 2000. Prieto Aretino: Las seis jornadas. La cortesana (Madrid: Cátedra, Letras Universales).

González Ollé, Fernando, 2000. 'Pretérito perfecto y condicional con desinencia -ie- en el siglo XVI', Revista de Filología Española, 80.3-4, pp. 341-77.

Gruber, Teresa María, 2008 [2006]. 'El español en Italia en el Siglo de Oro', in Nuevas perspectivas en torno a la diacronía lingüística: Actas del VI congreso Nacional de la AJIHLE, Granada, 29th-31st March 2006, roundtable ‘El español como lengua extranjera en el Siglo de Oro', ed. Esteban Tomás Montoro del Arco; Ma Ángeles López Vallejo and Francisco José Sánchez García (Granada: University of Granada), pp. 567-79.

- , 2014. Mehrsprachigkeit und Sprachreflexion in der Frühen Neuzeit. Das Spanische im Königreich Neapel. Romanica Monacensia 81. (Tübingen: Narr).

Guitarte, Guillermo, 1979. ‘¿Valdés contra Delicado?’, in Homenaje a Fernando Antonio Martínez: estudios de lingüística, filología, literatura e historia cultural, ed. Rubén Páez Patiño and Vicente Pérez Silva (Bogotá: Instituto Caro y Cuervo), pp. 147-67.

Iglesias Recuero, Silvia, 1998. 'Elementos conversacionales en el diálogo renacentista', in Competencia escrita, tradiciones discursivas y variedades lingüísticas: aspectos del español europeo $y$ americano en los siglos XVI y XVII, ed. Wulf Oesterreicher, Eva Stoll and Andreas Wesch. ScriptOralia 112. International Colloquium held in Freiburg, 26-28 September 1996. (Tübingen: Gunter Narr), pp. 385-419.

Krefeld, Thomas, Wulf Oesterreicher and Verena Schwägerl-Melchior (eds), 2013. Reperti di plurilingüismo nella Italia spagnola (sec. XVI-XVII) (Berlin: De Gruyter).

Koch, Peter, 1999. 'Court Records and Cartoons: Reflections of Spontaneous Dialogue in Early Romance Texts', in Historical Dialogue Analysis, ed. Andreas H. Jucker, Gerd Fritz and Franz Lebsanft. Pragmatics and Beyond New Series 66 (Amsterdam: John Benjamins), pp. 399-429.

Koch, Peter, and Wulf Oesterreicher, 2007 [1990]. Lengua hablada en la Romania: español, francés, italiano, trans. by Araceli López Serena of Gesprochene Sprache in der Romania, Französisch, Italienisch, Spanisch by Peter Koch and Wulf Oesterreicher (Madrid: Gredos [Tübingen: Max Niemeyer Verlag]).

Lyons, John, 1981. Language and Linguistics (Cambridge: Cambridge University Press).

Medina Morales, Francisca, 2005a. La lengua del Siglo de Oro: un estudio de variación lingüística (Granada: Universidad de Granada).

-, 2005b. El léxico de la novela picaresca, anejo LVII de Analecta Malacitana (Málaga: Universidad de Malága).

Navarro Tomás, Tomás, 1948. Manual de entonación española (New York: Hispanic Institute).

Oesterreicher, Wulf, 2004a. 'Textos entre inmediatez y distancia comunicativas. El problema de lo hablado escrito en el Siglo de Oro', in Historia de la lengua española, ed. Rafael Cano Aguilar (Barcelona: Ariel), pp. 729-69.

- , 2004b. 'Plurilingüismo en el Reino de Nápoles (siglos XVI Y XVII)', Lexis, XXVIII, 1-2: 217-57.

Pallotta, Augustus, 1991. 'Venetian Printers and Spanish Literature in Sixteenth-Century Italy', Comparative Literature, 43.1: 20-42.

Perugini, Carla (ed.), 2004. La Lozana andaluza (Seville: Fundación Lara).

Pountain, ChristopherJ., 2001. A History of the Spanish Language through Texts(Florence, KY: Routledge).

- , 2006. 'Towards a History of Register in Spanish', Spanish in Context, 3.1: 5-24.

-, 2016. 'Tradiciones de Discurso y Santa Teresa', Scriptum Digital, 5: 5-23.

Quilis, Antonio, 1999. Tratado de fonología y fonética españolas. Biblioteca Románica Hispánica, III, Manuales, 74 (Madrid: Gredos).

Sánchez Méndez, Juan Pedro (ed.), 2012. Oralidad y escritura en la Edad Media hispánica (Valencia: Tirant Humanidades).

Taddia, Elena, 2013. 'The Underworld, the City and the Night. Orality from Criminal Archives in Early Modern Italy', Paper presented at the conference ‘Gossip, Gospel, Governance: Orality in Europe 1400-1700', held at the British Academy, London, 5-7 July 2011. 
Vian Herrero, Ana, 1987. 'La mímesis conversacional en el Diálogo de la lengua de Juan de Valdés', Criticón, 40: 45-79.

- , 1988. 'La ficción conversacional en el diálogo renacentista', Edad de Oro, VII: 173-86.

Vigara Tauste, Ana María, 2005 [1992]. Morfosintaxis del español coloquial: esbozo estilístico (Madrid: Gredos). 
